\title{
PRAKTIK KOMUNIKASI VISUAL KEBERAGAMAAN METALHEAD INDONESIA DI MEDIA SOSIAL
}

\author{
Sujud Puji Nur Rahmat \\ Universitas Mercu Buana
}

\begin{abstract}
Abstrak. Hadirnya media sosial Facebook, mengubah kebiasaan interaksi metalhead, yang awalnya bertemu langsung secara fisik beralih menjadi cara komunikasi visual. Komunikasi visual yang ditampilkan metalhead melalui Facebook beragam, mulai tulisan, foto, gambar atau poster, hingga video. Di Indonesia, metalhead juga menggunakan Facebook sebagai media komunikasi dengan sesama metelhaed dan masyarakat umum. Namun, dalam penggunaan Facebook metalhead Indonesia tidak menunjukan adanya tanda-tanda perlawanan. Sebaliknya, sebagian metalhead Indonesia justru memanfaatkan Facebook sebagai bentuk praktik keberagamaannya. Praktik kemusik-metalan yang identik dengan perlawanan tentu berbeda dengan praktik keberagamaan yang identik dengan hubungan baik antar-manusia. Praktik visual keberagamaan metalhead adalah perpaduan antara praktik kemusik-metalan dan praktik keberagamaan. Tulisan ini bermaksud memamparkan praktik kemusik-metalan dan keberagamaan sekaligus secara visual yang dilakukan metalhead Indonesia melalui Facebook. Metode campuran antara etnografi konvensional dan etnografi virtual digunakan mengobservasi objek penelitian untuk mendapatkan data-data yang dibutuhkan. Berdasarkan analisis didapatkan tiga fenomena yang biasa dilakukan metalhead seluruh dunia maupun di Indonesia, yaitu dari (1) bunyi musik metal, (2) sikap komunikasi verbal, gestur, dan mimik muka sehari-hari, (3) visual desain logo dan ilustrasi; sedangkan di Indonesia terdapat tambahan fenomena baru, yaitu (4) komunikasi visual keberagamaan di Facebook.
\end{abstract}

Kata Kunci: metalhead, praktik, komunikasi visual, keberagamaan, media sosial.

\begin{abstract}
The presence of social media such as Facebook has changed the habit of interaction among the metalheads. In other words, through the study the researcher would like to investigate how the Indonesian metalheads manage the visual aspect in the practice of their religion and also to investigate why the Indonesian metalheads certain articles, photos, pictures and videos are selected, posted and disseminated through Facebook as the medium of visual communication for their religion. Mixed method ethnography conventional and virtual ethnography method has been selected in order to attain the relevant data within the observation toward the object of the study. Based on the results of the analysis, the researcher has found three general stages that the metalheads throughout the world undergo namely: (1) the sound of metal music; (2) the verbal communication attitude, the gesture and the facial expression in the context of daily life; and (3) the visual design of logo and illustration; while for the Indonesian metalheads, there is another stage namely: (4) the visual communication of religion in Facebook.
\end{abstract}

Keywords: metalhead, practice, visual communication, religion, social media.

Correspondence author: Sujud Puji Nur Rahmat, sujud.puji@mercubuana.ac.id, Jakarta, Indonesia 


\section{Pendahuluan}

Objek material IImu komunikasi adalah tindakan manusia dalam konteks sosial sama seperti sosiologi atau antropologi misalnya, sehingga masuk dalam rumpun ilmu-ilmu sosial. Sedangkan objek formal ilmu komunikasi adalah komunikasi itu sendiri (Vardiansyah 1), dalam tulisan ini lebih fokus pada salahsatu bentuk komunikasi yaitu komunikasi visual. Komunikasi visual adalah ilmu yang mempelajari konsep komunikasi dan ungkapan daya kreatif yang diaplikasikan dalam berbagai media komunikasi visual guna menyampaikan pesan kepada target atau sasaran yang dituju (Tinarbuko 5 ). Komunikasi visual adalah komunikasi yang dilakukan dua orang/kelompok atau lebih dengan menggungan komunikasi visual dimedia visual. Ide atau gagasan yang dimiliki kumikator disampaikan kepada komunikan melalui media visual yang di dalamnya terdapat elemen visual. Pada era teknologi komunikasi internet yang canggih seperti saat ini, di mana tumbuh dan berkembangannya media sosial, sehingga mempertemukan yang sulit bertemu dan memperpendek jarak yang jauh menjadi terasa dekat. Media sosial, yang merupakan sebagai media visual digunakan dan bahkan tidak lepas dari kehidupan sehari-hari para penggunaanya. Media sosial, seperti dahulu bernama Myspace, dan sekarang muncul bernama Facebook serta Whatsapp, juga digunakan para metalhead Indonesia. Dengan menggunakan internet semua orang bisa mendapatkan informasi dan juga dapat menginformasikan, mulai dari kesenian, ekonomi, politik, olahraga dan lain-lain. Internet, sebagai media baru, seolah meruntuhkan batas-batas kaku ruang dan waktu, memungkinkan banyak tempat yang secara geografis berjauhan bisa terhubung dalam satu waktu, meningkatkan keterhubungan, serta dapat juga mendorong migrasi dan diaspora (Mazierska 3).

Seperti apa yang dikatakan Rahmat et al. "Internet Dan Musik: Media Sosial Sebagai Wahana Publikasi the Upstairs Dan Death Flames" bahwa penggunaan media sosial sebagai media dan komunikasi visual antar-metalhead Indonesia, sudah terjadi pada tahun 2003 sampai 2009 di Myspace. Setelah tahun 2009 hingga saat ini, media sosial yang digunakan sebagai media sekaligus komunikasi visual antar-metal berpindah dari Myspace ke Facebook serta Whatsapp. Enam belas tahun dari dua puluh sembilan tahun keberadaan musik metal di Indonesia-musik metal di Indonesia muncul sekitar pada tahun 1990-an-,komunikasi antar-metalhead dilakukan dengan media visual melalui media-media sosial tersebut. Seperti yang dikemukakan oleh Jones (448), internet penting untuk membangun citra sebuah band untuk kemudian ditampilkan atau dipresentasikan kepada publik penggemarnya. Tampaknya media sosial ke depannya akan tetap digunakan oleh para metalhead sebagai media dan komunikasi visual selama media sosial masih ada dan menguntungkan bagi mereka. Tergambar jelas bahwa media sosial tidak bisa lepas dari kehidupan sehari-hari para metalhead Indonesia; dan juga media sosial turut andil dalam perkembangan musik metal di Indonesia.

Berawal dari sekedar sebagai media komunikasi, komunikasi visual akhirnya menjadi sebuah budaya bagi para metalhead Indonesia. Para metalhead Indonesia dalam penggunaan media visual telah melampaui sebagai peristiwa komunikasi. Pelampauan tersebut dilakukan dengan cara memproduksi, menyalurkan, mengomunikasikan, dan memahami media visual. Terkait sifatnya yang sudah menjadi budaya, media visual sebagai jembatan komunikasi para metalhead Indonesia perlu adanya kajian tersendiri. Kajian berfokus pada dugaan adanya sesuatu di balik budaya visual melalui memahami praktik kevisualan yang dilakukan para metalhead Indonesia dalam bermedia sosial sehari-hari. Selain itu, pengalaman pertemuan secara langsung di dalam lingkungan kehidupan sehari-hari secara fisik para metalhead Indonesia juga dianggap perlu dan penting sebagai upaya memahami budaya metalhead Indonesia. 
Pengalaman pertemuan penulis secara langsung di dalam lingkungan kehidupan seharihari para metalhead Indonesia dijadikan sebagai penilaianuntuk memahami budaya visual yang diproduksi para metalhead Indonesia di Facebook. Hasilnya terdapat kesamaan antara kehidupan sehari-hari dan komunikasi visual melalui media sosial yang dilakukan metalhead Indonesia, yaitu terkait praktik keberagamaan. Praktik keberagamaan yang diterapkan metalhead Indonesia adalah agama Islam. Praktik keberagamaan para metalhead Indonesia di kehidupan sehari-hari dan komunikasi visual di Facebook mencerminkan bahwa mereka adalah bukan sub-kultur seperti yang dilakukan metalhead luar negeri. Praktik keberagamaan sudah terlebih dahulu ada dan dipraktikkan oleh masyarakat lain di Indonesia sebelum adanya komunitas musik metal baik di luar maupun di dalam Indonesia. Keberadaan subkultur sebenarnya tercipta untuk melawan budaya yang telah ada dan mapan. Tetapi praktik keberagamaan dari budaya lain juga dipraktikan oleh metalhead Indonesia yang tergabung baik dalam komunitas musik metal itu sendiri maupun komunitas non-musik metal tetapi hanya bersifat sementara atau subkultur-temporer metalhead Indonesia (Rahmat 351).

Penggunaan Facebook sebagai komunikasi visual merupakan menjadi bagian dari kehidupan sehari-hari metalhead Indonesia. Dalam praktiknya, komunikasi visual digunakan untuk membantu agar pesan yang dinginkan tersampaikan dan dimengerti kepada orang yang dituju. Selama menggunakan media sosial, sejak dahulu Myspace hingga kini Facebook, metalhead Indonesia memiliki cara tersendiri dalam keberlangsungan komunikasi visual di media sosial, yaitu komunikasi visual sebagai awal komunikasi visual dan pengelolan komunikasi visual sebagai mempertahankan keberadaan komunikasi visual.

Tulisan ini bermaksud untuk mengungkapkan proses yang dilakukan metalhead Indonesia dalam praktik komunikasi visual. Proses tersebut dimaksudkan sebagai tahap awal dalam berkomunikasi visual di Facebook. Prosesnya terdapat empat tahap yang dilakukan secara bertahap satu persatu sesuai urutannya, yaitu memproduksi, menyalurkan, mengomunikasikan, dan memahami komunikasi visual. Setelah melakukan keempat tahapan sebagai awal komunikasi visual, selanjutnya terdapat tahap lain. Tahap yang lain tersebut adalah pengelolaan komunikasi visual. Adanya pengelolaan komunikasi visual karena didasari kesesuaian dan kelanjutan tema yang sebelumnya sudah dibahas pada proses awal komunikasi visual. Pengeloaan komunikasi visual merupakan suatu upaya mempertahankan pembahasan suatu tema yang dilakukan secara terus menurus melalui bermacam jenis komunikasi visual.

\section{Metode Penelitian}

Metode yang digunakan dalam mengumpulkan data adalah secara etnografi konvensional atau partisipant observer mengacu pada penjelasan (Spradley 13), bahwa etnografi merupakan metode penelitian yang dikhususkan untuk memahami aspek kultural dalam masyarakat meliputi teknik penelitian, teori etnografis, dan berbagai macam deskripsi kebudayaan yang bermakna untuk membangun suatu pengertian yang sistemik terhadap suatu kebudayaan yang ia pelajari sebelumnya. Selain itu juga menggunakan etnografi virtual atau searching di media sosial, sebagaimana yang dikemukakan Nasrullah (1) di jaman sekarang etnografi bukan sekedar mengekplorasi catatan-catatan tentang artefak kebudayaan saja, melainkan juga meneliti lebih mendalam bagaimana artefak itu bisa ada dan berlaku di sebuah kelompok, salah satunya fenomena di media sosial facebook yang menjadi semacam ruang pribadi untuk mengunggah apa saja yang ada di sekitar mereka. 


\section{Hasil dan Pembahasan}

Memproduksi komunikasi visual adalah sebuah kegiatan yang dilakukan seseorang secara perorangan sebelum atau saat aktivitas online Facebook. Karya seni pertunjukan yang diproduksi diharapkan dapat memperluas pemahaman kita tentang politik indrawi Islam, serta praktik estetika dan etika, di dunia di mana hiburan, rekreasi, dan industri budaya dianggap semakin menentukan keberlanjutan budidaya diri yang saleh (Jouili). Jenis komunikasi visual terdiri dari tulisan, foto, meme, poster atau gambar, maupun video. Seseorang disebut sebagai produsen komunikasi visual apabila memproduksi satu atau semua jenis komunikasi visual tersebut. Aktivitas metalhead Indonesia yang dilakukan serhari-hari di media sosial juga disebut sebagai produsen komunikasi visual. Berbagai macam tema komunikasi visual yang diproduksi oleh metalhead Indonesia, antara lain mengenai festival musik metal, karya dan biografi band musik metal dalam maupun luar negeri, atribut musik metal dalam dan luar negeri, dan keberagamaan.

Penyaluran komunikasi visual adalah sebuah upaya awal terbukanya komunikasi visual di Facebook antara penyalur dan pengguna Facebook lainnya. Maksud dari pengguna Facebook lainnya merupakan akun Facebook yang berteman dengan penyalur komunikasi visual. Jenis komunikasi visual yang disalurkan oleh penyalur, antara lain tulisan, foto, meme, maupun video. Metalhead Indonesia selain meproduksi komunikasi visual juga menyalurkan komunikasi visual di Facebook. Pencitraan (image) yang terbentuk dari artis/band itu merupakan persepsi yang ditangkap publik saat menerima informasi apa pun yang diberikan artis/band tersebut secara konstan, misalnya yang ditimbulkan dari musik, lirik, gaya/penampilan, attitude, sampul album dan desain merchandise hingga opini sang artis. Tema komunikasi visual yang disalurkan meliputi mengenai festival musik metal, karya dan biografi band musik metal dalam maupun luar negeri, atribut musik metal dalam dan luar negeri, dan keberagamaan. Namun, jenis komunikasi visual yang disalurkan metalhead Indonesia tidak hanya yang diproduksi sendiri, juga yang diproduksi oleh temannya di Facebook.

\section{Mengomunikasikan dan Memahami Komunikasi visual}

Komunikasi melalui komunikasi visual adalah hubungan antar-dua orang atau lebih membahas suatu tema dengan menggunakan berbagai jenis komunikasi visual salah satunya di media Facebook. Di Facebook, disediakan kolom komentar bagi yang ingin berkomunikasi lebih lanjut secara mendalam sesuai dengan jenis dan tema komunikasi visual yang disalurkan oleh seseorang. Metalhead Indonesia berkomunikasi melalui komunikasi visual dengan berbagai tema dan jenis komunikasi visual. Jenis komunikasi visual yang dikomunikasikan oleh metalhead Indonesia adalah tulisan, foto, meme, maupun video. Sedangkan tema yang dikomunikasikan melalui jenis komunikasi visual adalah festival musik metal, karya dan biografi band musik metal dalam maupun luar negeri, atribut musik metal dalam dan luar negeri, dan keberagamaan.

Memahami komunikasi visual adalah mengetahui maksud dari tema yang dikomunikasikan melalui jenis komunikasi visual yang disalurkan di Facebook. Berbagai macam tema yang dikomunikasikan antar-sesama metalhead Indonesia adalah sesuai dengan apa yang dapat dipahami oleh mereka, yaitu festival musik metal, karya dan biografi band musik metal dalam maupun luar negeri, atribut musik metal dalam dan luar negeri, dan keberagamaan. Memasukkan seni visual sebagai upaya menghadirkan yang dapat dikenali dalam objek sebagai sebuah logo yang cukup dikenal oleh publik muslim di Indonesia (George).

Proses memahami tersebut berdasarkan adanya keterhubungan antara kehidupan sehari-hari metalhead Indonesia secara langsung dengan praktik komunikasi visual yang dipraktikan di Facebook. Esensi dari kemunculan hingga bertahannya bentuk komunikasi visual 
merupakan adanya keterkaitan tema yang dibahas dan pengalaman yang dialami metalhead Indonesia. Hal tersebut merupakan sebuah transformasi pengalaman yang berawal dari kehidupan sehari-hari secara langsung yang berbentuk fisik menjadi ke yang berbentuk visual saja. Kehidupan sehari-hari yang fisik dalam suatu tema tersebut yang membentuk suatu pengalaman yang membawa kepada peristiwa kehidupan dalam komunikasi visual tidak mesti selalu merupakan sebuah perjumpaan antara sesama metalhead Indonesia. Bisa juga, masingmasing metalhead Indonesia melakukan kehidupan fisik sehari-hari tidak bersama sesama metalhead. Tetapi metalhead melakukan kehidupan sehari-hari secara fisik sendiri-sendiri di mana pun mereka berada di dalam suatu lingkungan.

\section{Materi Komunikasi Visual Keberagamaan Metalhead Indonesia di Facebook}

Festival musik metal, karya dan biografi band musik metal dalam maupun luar negeri, dan atribut band musik metal dalam dan luar negeri, adalah tema yang sering dikomuniksikan metalhead Indonesia di Facebook. Selain itu, terdapat satu tema lain yang juga sering dikomunikasikan dan merupakan sebagai khas metalhead Indonesia, yaitu kebergamaan. Materi visual tema keberagamaan yang dipraktikan metalhead Indonesia di Facebook terdapat tujuh metode, yaitu pertama, menampilkan foto profil dan foto sampul; kedua, mempraktikan opini pribadi keagamaan secara langsung di Facebook; ketiga, mengajak sesama Muslim agar beribadah secara langsung di Facebook; keempat, sebelumnya dipraktikan di luar Facebook lalu didokumentasikan dan disebar di Facebook; kelima, menyebarkan informasi dan pengetahuan yang didapati di Facebook;keenam, menyiarkan secara langsung kegiatan kebergamaan yang dilakukan melalui aplikasi video Facebook; dan, ketujuh, menyebarkan segala informasi tentang band musik metal Islami dari dalam negeri.

Jenis komunikasi visual bertema keberagamaan yang komunikasikan metalhead Indonesia adalah tulisan, foto, meme, video rekaman, dan video siaran langsung. Hal tersebut juga merupakan sebuah ungkapan menyuruh kepada kebaikan jika terbukti kebaikan ditinggalkan (tidak diamalkan), dan melarang dari kemungkaran jika terbukti kemungkaran dikerjakan (hisbah) untuk mencari hubungan antara kegiatannya dan pengembangan seni dan kerajinan dalam Islam (Stilt). Materi keberagamaan yang dijadikan komunikasi visual antara lain, mulai dari pendapat atau hasil pemikirannya sendiri, mengutip ayat-ayat Al-quran serta hadis Nabi Muhammad SAW, pendapat atau pandangan tokoh-tokoh Islam dari dalam maupun luar negeri, hingga pendapat dari warga muslim baik yang metalhead maupun non-metalhead.

Praktik komunikasi visual kebergamaan dilakukan secara perseorangan masing-masing metalhead Indonesia. Selain itu, teknis berkomunikasi visual dengan sesama teman Facebooknya pun juga beragam cara. Kegiatan keberagamaan rupanya tidak bisa dilepaskan dari kehidupan sehari-hari metalhead Indonesia, mulai dari kehidupan secara fisik lalu bertransformasi ke dalam komunikasi visual di Facebook. Selain itu, bisa kembali bertransfomrasi dari komunikasi visual di Facebook ke dalam kehidupan secara fisik dan kembali bertransformasi ke dalam komunikasi visual di Facebook.

\section{Pengelolaan Komunikasi Visual yang Bertransformasi ke Media Facebook}

Pengelolaan komunikasi visual merupakan sebagai bentuk upaya menindaklanjuti pembahasan tema yang sebelumnya telah diperbincangkan pada awal komunikasi visual di Facebook. Penindaklanjutan tersebut terdapat dua tahap yang berbeda satu sama lain. Pertama, penindaklanjutan yang masih tetap dalam komunikasi visual di Facebook. Penindaklanjutan tahap yang pertama ini memungkinkan selalu lebih awal terjadi ketimbang penindaklanjutan tahap yang lain; dan penindaklanjutan seperti ini selalu terjadi secara berulang-ulang karena masih satu media, yaitu di Facebook. 
Peristiwa Kehidupan Sehari-hari secara Fisik

\author{
$\downarrow$ \\ Awal Komunikasi Visual di Facebook
}

Gambar 1 Transformasi Komunikasi Metalhead Indonesia Konstruk oleh Sujud Puji Nur Rahmat, 2019

Terdapat banyak penjelasan mengapa, penindaklanjutan ke tahap pertama ini bisa selalu terjadi terlebih dahulu ketimbang yang lainnya. Penjelasannya adalah: 1) tidak perlu mengubah bentuk atau bertransformasi, 2) masih dalam satu momen waktu, 3) waktu yang digunakan dalam merespon sangat cepat, 4) tema dan jenis komunikasi visual sebagai pembahasan dapat diulang-ulang dan bisa dilihat dari berbagai sudut sehingga menimbulkan banyak ide bahan perbincangan, 5) bahan pembahasan sebagai tema komunikasi visual dapat dibahas secara cepat dalam satu waktu antara kejadian dan perbincangan walaupun lokasinya yang berjauhan, 6) daya visual lebih menarik daripada suara, dan 7) daya visual lebih bebas dan nyaman daripada bertatap muka atau fisik secara langsung.

Pengelolaan Komunikasi Visual di Facebook

Tetap Berkomunikasi Visual di Facebook
Transformasi ke Komunikasi

Kehidupan Sehari-hari secara Fisik

\title{
Transformasi ke Komunikasi Visual di Facebook Selalu Berulang-ulang Bertransformasi antara Kehidupan Sehari-hari Fisik dan Komunikasi Visual di Facebook
}

Gambar 2 Pola Pengelolaan Komunikasi Visual dan Tahap Penindaklanjutan Konstruk oleh Sujud Puji Nur Rahmat, 2019

Sedangkan kedua, penindaklanjutan yang dari komunikasi visual di Facebook bertransformasi ke dalam kehidupan sehari-hari secara fisik terdapat sebaliknya dari penjelasan yang penindaklanjutan masih tetap dalam komunikasi visual di Facebook. Apabila awal komunikasi visual adanya upaya transformasi dari peristiwa perjumpaan kehidupan sehari-hari secara fisik mejadi peristiwa penjumpaan praktik komunikasi visual di Facebook. Sedangkan pengelolaan komunikasi visual adanya upaya menindaklanjuti pembahasan sebelumnya dari awal komunikasi visual di Facebook dan berlanjut tetap berkomunikasi visual di Facebook atau kembali transformasi/misi ke komunikasi kehidupan sehari-hari secara fisik. Nurgivantoro mengemukakan, transformasi adalah perubahan suatu hal atau keadaan. Bentuk perubahan, adakalanya berubah kata, kalimat, struktur, dan isi. Selain itu transformasi juga bisa dikatakan, pemindahan atau pertukaran suatu bentuk kebentuk lain, yang dapat menghilangkan, memindahkan, menambah, atau mengganti unsur seperti transformasi dari nyata ke media sosial. Hal ini sesuai dengan ungkapan Damono (46) yang mengatakan alih wahana pasti menghasilkan jenis kesenian atau bentuk yang berbeda. Apabila terjadi adanya dari awal komunikasi visual di Facebook lalu kembali transformasi ke komunikasi kehidupan sehari-hari 
secara fisik, kemungkinan akan kembali kepada transformasi ke komunikasi visual di Facebook. Keterkaitan antara kehidupan sehari-hari secara fisik dan komunikasi visual di Facebook, tidak hanya terjadi secara satu arah. Tetapi bisa terjadi dua arah, yaitu: pertama, transformasi dari kehidupan sehari-hari secara fisik ke komunikasi visual di Facebook; kedua, transformasi/misi dari komunikasi visual di Facebook ke kehidupan sehari-hari secara fisik.

\section{Menampilkan Foto Profil dan Foto Sampul}

Pada metode ini dalam praktik visual kebergamaan metalhead Indonesia adalah umumnya menggunakan jenis komunikasi visual foto. Komunikasi visual visual foto tersebut, digunakan pada bagian tampilan di akun Facebook. Terdapat dua pada bagian tampilan, yaitu foto profil dan foto sampul. Tampilan ukuran foto profil tidak sebesar tampilan ukuran foto sampul, yang mencapai delapan kali lipat. Foto profil dan foto sampul sebagai tampilan awal bagi orang lain ingin mengenal akun Facebook milik orang lain. Tampilan awal dianggap merupakan cerminan dari pemilik akun Facebook sebelum megenal lebih jauh lagi. Namun, bagi metalhead Indonesia yang berpraktik visual keberagamaan di Facebook, terdapat lima tipe dalam memanfaatkan foto profil dan foto sampul di akun Facebooknya. Pada tahap komunikasi visual ini, belum bisa dianggap metalhead Indonesia pemilik akun Facebook sedang berpraktik keberagamaannya.

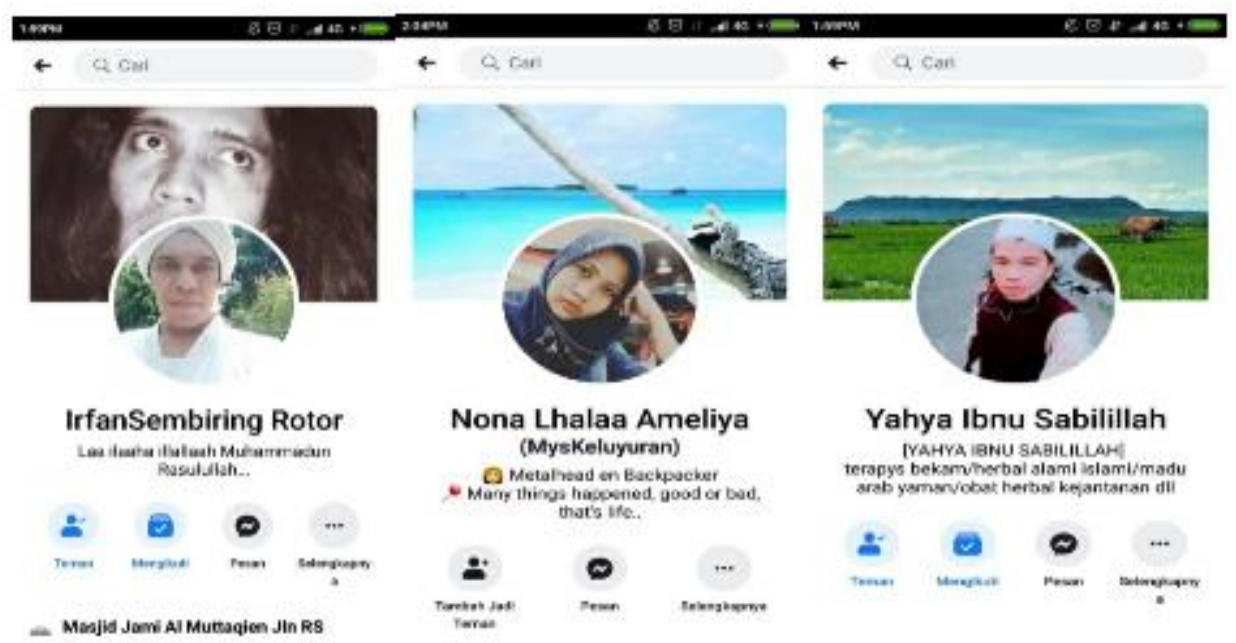

Gambar 3 Satu dari lima tipe tampilan foto profil metalhead Indonesia yang ditampilkan di Facebook. Sumber: Sujud Puji Nur Rahmat, 2019.

Tipe pertama, metalhead Indonesia menggunakan pakaian busana muslim yang umumnya digunakan kelompok Islam lain. Tipe kedua, metalhead Indonesia yang menggunakan suasana kegiatan keberagamaannya sebagai foto profil dan foto sampul. Tipe ketiga, metalhead Indonesia yang tidak menggunakan suasana kegiatan keberagamaannya sebagai foto profil dan foto sampul tetapi menggunakan suasana kegiatan kemusik-metalannya yang digunakan sebagai foto profil dan foto sampul. Tipe keempat, metalhead Indonesia yang tidak menggunakan suasana kegiatan keberagamaan dan kemusik-metalannya sebagai foto profil dan foto sampul tetapi mengunakan suasana kegiatan lainnya yang digunakan sebagai foto profil dan foto sampulnya. Tipe kelima, metalhead Indonesia yang tidak memanfaatkan foto profil dan foto sampul sama sekali sehingga terlihat kosong. 


\section{Mempraktikan Opini Pribadi Keberagamaan secara Langsung di Facebook}

Pada metode ini dalam praktik visual kebergamaan metalhead Indonesia adalah menggunakan jenis komunikasi visual tulisan. Pada metode pertama praktik visual kebergamaan ini, tidak bisa mengguna jenis komunikasi visual selain tulisan. Bentuk tulisan kebergamaannya pun juga beragam jumlahnya, dimulai yang satu kata, lalu satu kalimat, bahkan hingga satu paragraf atau lebih. Bahasa tulisan yang digunakan dalam metode praktik visual kebergamaan ini, umumnya menggunakan bahasa Indonesia dan terkadang menggunakan bahasa daerah, yaitu bahasa Jawa. Penggunaan bahasa Indonesia yang dipraktikan, tidak berdasarkan cara yang semestinya, yaitu berbahasa yang baik dan benar.

Penggunaan bahasa Indonesianya pun, cenderung seadanya atau SPOK-nya tidak lengkap, dan terkadang bercampur dengan bahasa gaul. Selain itu, saat menulis penggunaan tanda baca juga terkesan semaunya dan tidak sesuai dengan kaidah yang berlaku dalam berbahasa Indonesia. Berdasarkan cara berkomunikasi visual melalui komunikasi visual dengan metode tulisan yang dilakukan metalhead Indonesia, menyiratkan akan tiga hal. Pertama, ketidakmampuan dalam menggunakan bahasa Indonesia yang baik dan benar, berikut dengan penggunaan tanda baca. Kedua, metalhead Indonesia mampu menggunakan bahasa Indonesia dan tanda baca yang baik dan benar, tetapi tidak digunkan karena penggunaan bahasa Indonesia dan penggunaan tanda baca yang baik dan benar tidak diperlukan dalam berkomunikasi visual di Facebook. Ketiga, metalhead Indonesia menganggap bahwa dalam berkomunikasi visual lebih tepat dan efektif apabila tidak menggunakan bahasa Indonesia dan tanda baca yang baik dan benar.

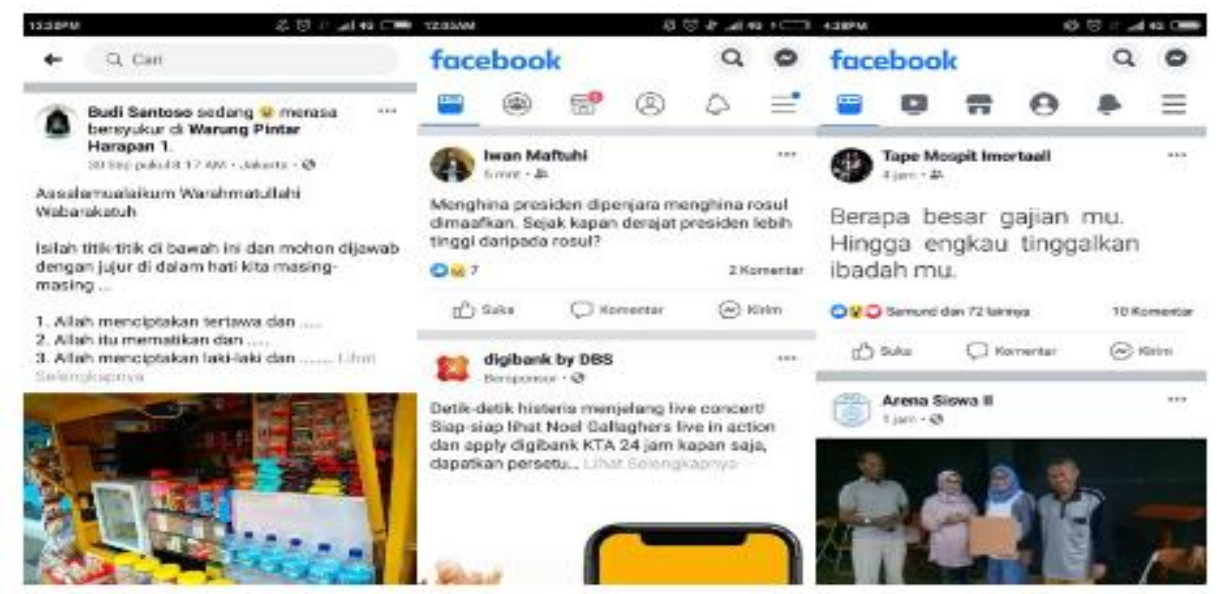

Gambar 4 Metalhead Indonesia mempraktikan visual keberagamaan dengan menggunakan jenis komunikasi visual tulisan di Facebook. Sumber: Sujud Puji Nur Rahmat, 2019.

Muatan tulisan yang bermacam jumlahnya tersebut, juga terdapat beragam pesan, ada yang berupa sebuah pertanyaan maupun pernyataan. Ide dasar pesan yang disampaikan tersebut, baik pertanyaan maupun pernyataan, merupakan berasal dari dua gagasan. Gagasan pertama, dari pemikirannya sendiri; sedangkan gagasan kedua, merupakan menindaklanjuti pembicaraan keberagamaan dengan menggunakan metode tulisan yang sebelumnya sudah dilakukan bersama teman-teman Facebooknya pada peristiwa yang berbeda yang lalu ditafsirkan dan kembali ditulis ulang dengan pembahasan yang lain. Ragam pesan pertanyaan dan pernyataan tersebut, akhirnya menjadi pemicu komunikasi visual selanjutnya dengan ditanggapi oleh teman Facebooknya, baik sesama metalhead maupun non-metalhead. Merasa pertanyaan atau pernyataannya ditanggapi, metalhead Indonesia pembuat tulisan tersebut, menyambut kembali tanggapan teman Facebooknya. Namun, tanggapan dari teman Facebook 
atas tulisan yang dibuatnya beragam. Mulai dari menyetujui atas gagasan yang disampaikan, berbeda padangan lalu disampaikan secara halus, hingga kontra pendapat sampai muncul perdebatan yang panjang. Ragam tanggapan tersebut, juga dilakukan metalhead pembuat tulisan komunikasi visual dalam menanggangapi tanggapan dari teman Facebooknya di kolom komentar di bawah jenis komunikasi visual. Namun, segala jenis komunikasi visual yang diunggah metalhead Indonesia bisa diubahnya.

Pengubahan komunikasi visual yang dilakukannya adalah yang telah diunggahnya, terutama pada tulisan. Pengubahan yang dilakukan, antara lain mengurangi, menambahkan, dan menggantinya. Selain diubah, segala jenis komunikasi visual yang telah diunggah juga bisa dihapus. Pengubahan dan penghapusan terkait komunikasi visual yang telah diunggah juga bisa dilakukan pada tanggapan di kolom komentar. Pengubahan dan pengahapusan dilakukan karena diangga ketidaksesuaian setelah jenis visual diunggahnya.

\section{Mengajak Sesama Muslim agar Beribadah secara Langsung di Facebook}

Pada metode ini dalam praktik visual kebergamaan metalhead Indonesia adalah menggunakan jenis komunikasi visual tulisan, foto, dan poster. Komunikasi visual tulisan, foto, dan poster yang diunggah metalhead Indonesia dalam jumlah mulai dari satu hingga lebih. Tujuan dibuatn komunikasi visual oleh metalhead Indonesia ini untuk sebagai bahan komunikasi visualnya sehingga menjadi pesan. Di balik pesan yang disampaikan tersebut, merupakan sebuah ajakan dari metalhead Indonesia kepada metalhead Indonesia lainnya dan masyarakat umum. Ajakan yang dimaksud untuk melaksanakan kegiatan keagamaan. Kegiatan keagamaan tersebut, seperti solat Jumat dan magrib, pengajian tema tertentu, dan solawat. Kegiatankegiatan keagamaan tersebut, merupakan rutin yang diwajibakan agama dan komunitas keagamaan yang diselenggarakan masyarakat umum.

Pelaku atau peserta kegiatan keagamaan bercampur antara metalhead Indonesia dengan masyarakat umum. Khususnya kegiatan keagamaan solat magrib dan solawat, bisa dilakukan sendiri oleh yang bersangkutan. Jadi, di balik pesan yang disampaikan berupa sebuah pengingat saja. Praktik visual keberagamaan pada materi ini, dapat dilakukan karena adanya momen tertentu. Metalhead Indonesia tidak bisa membuat materi sendiri. Berbeda dengan praktik visual keberagamaan sebelumnya, yaitu menampilkan foto profil dan mempraktikan opini pribadi keagamaan secara langsung di Facebook, di mana bisa dibuat dan disebarkan sendiri sesuka hati pembuatnya tanpa harus ada momen tertentu.

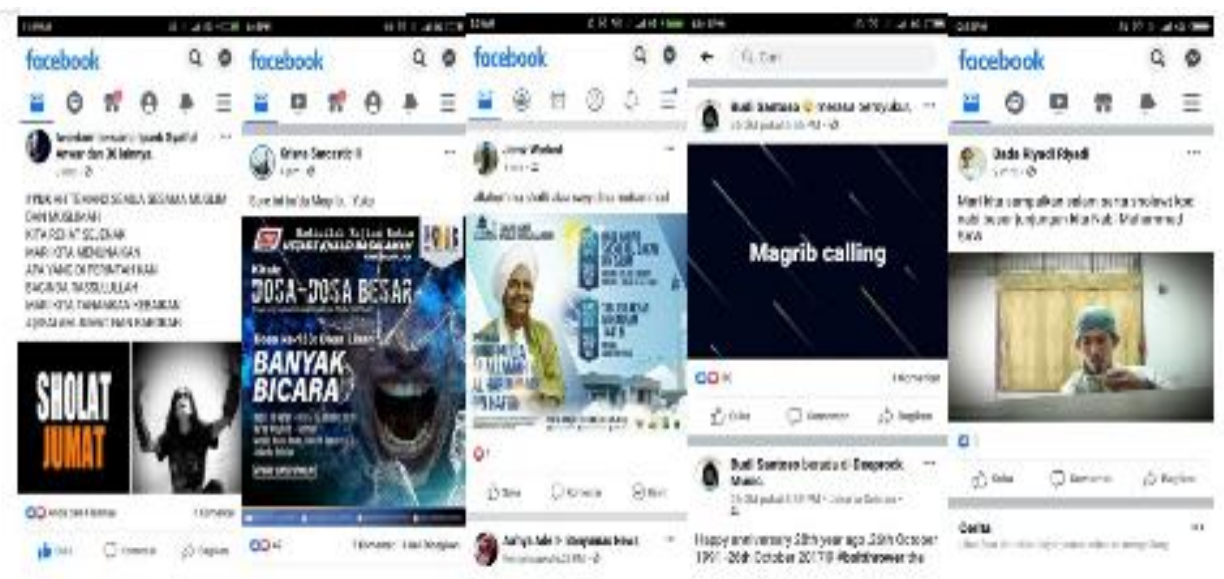

Gambar 5 Aktivitas Keberagamaan di Facebook.

Sumber: Sujud Puji Nur Rahmat, 2019 


\section{Dipraktikan di Luar Facebook lalu Didokumentasikan dan Disebar di Facebook}

Pada metode ini dalam praktik visual kebergamaan metalhead Indonesia hanya menggunakan dua jenis komunikasi visual, yaitu foto dan video. Komunikasi visual foto dan video yang diunggahnya metalhead Indonesia dalam jumlah mulai dari satu hingga batas maksimum yang diperbolehkan Facebook, yaitu tiga puluh buah foto atau video. Komunikasi visual ini paling sering dipraktikan metalhead Indonesia dari pada komunikasi visual lainnya. Dalam komunikasi visual foto dan video lebih utama menampilkan tempat dan keadaan sekitar saat praktik keberagamaan dilakukan metalhead Indonesia. Tempat dan keadaan sekitarnya dalam praktik komunikasi visual kebergamaan metalhead Indonesia pun terdapat dua macam.

Pertama, tempat dan keadaan sekitar dalam praktik keberagamaan yang merupakan bukan tempat dan keadaan sekitar umumnya tempat dan keadaan sekitar digunakan dalam keberagamaan. Pada tempat dan keadaan sekitar yang pertama ini, adalah hanya diperuntukan untuk metalhead Indonesia saja atau disebut praktik keberagamaan khusus. Tempat dan keadaan sekitar tersebut, merupakan praktik keberagamaan yang diinisiasi oleh para metalhead Indonesia. Dengan begitu, maka praktik kebergamaan tersebut dihadiri dan dipenuhi metalhead Indonesia. Penyelenggaraan praktik keberagamaan yang diselenggarakan para metalhead Indonesia, pakaian yang digunakan pun beragam: ada yang menggunakan pakaian umumnya umat Muslim Indonesia lainnya menggunakannya saat praktik kebergamaan, ada yang menggunakan pakaian resmi dalam acara-acara formal yang digunakan masyakarat Indonesia lainnya, danada yang menggunakan pakaian musik metal.

Kedua, tempat dan keadaan sekitar dalam praktik keberagamaan yang merupakan tempat dan keadaan sekitar umumnya tempat dan keadaan sekitar digunakan dalam kebergamaan. Pada tempat dan keadaan sekitar yang kedua ini, adalah umumnya ditempati dan dilakukan umat Muslim Indonesia lainnya atau disebut praktik keberagamaan umum. Tempat dan keadaaan sekitar tersebut, merupakan praktik keberagamaan yang diinisiasi umat Muslim lainnya. Dengan begitu, metalhead Indonesia bercampur dengan umat Muslim lainnya yang merupakan mayoritas dari keseluruhan yang hadir. Penyelenggaraan praktik keberagamaan umum ini, diselenggarakan oleh umat Muslim lainnya dan metalhead Indonesia hanya sebagai peserta saja. Penyelenggaraan praktik keberagamaan yang diselenggarakan umat muslim Indonesia lainnya, pakaian yang digunakan terdapat dua macam: ada yang menggunakan pakaian umumnya umat Muslim Indonesia menggunakannya saat praktik kebergamaan, dan ada yang menggunakan pakaian seragam komunitas umat Muslim Indonesia tertentu. Bahkan, Wallach (17-18) mengatakan bahwa kemunculan musik Metal di Indonesia-yang ia sebut dengan underground music-antara lain sebagai respon terhadap keadaan demokrasi di negeri ini. Hal inilah yang dipraktikkan dalam komunikasi visual yang mereka hadirkan lewat facebook. 


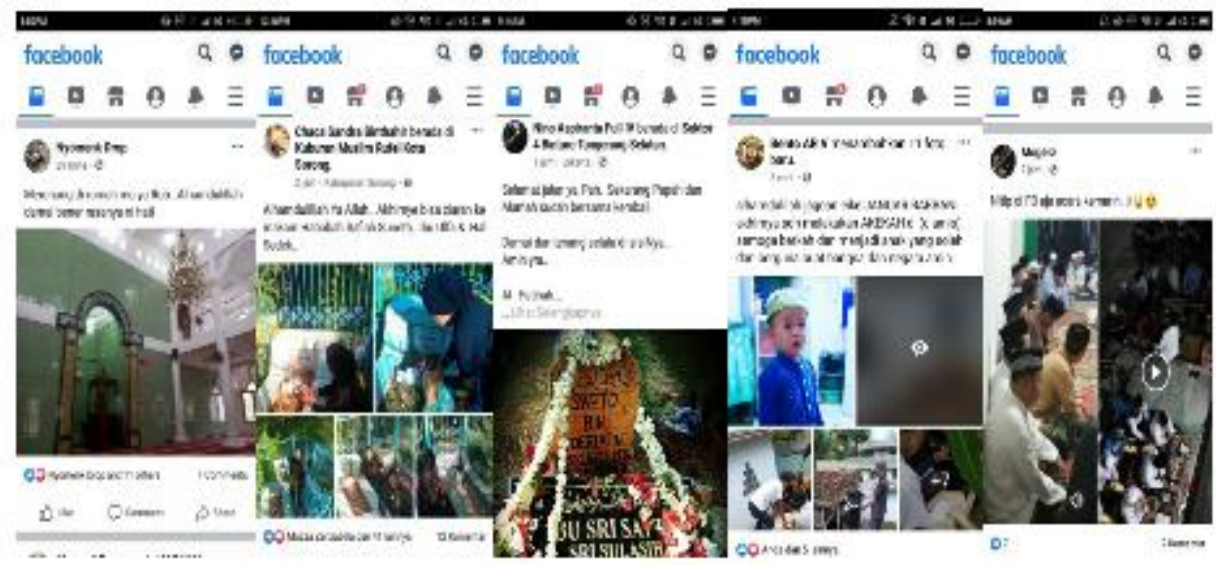

Gambar 6 Metalhead Indonesia mempraktikan visual kebergamaan dengan menggunakan jenis komunikasi visual foto di Facebook. Sumber: Sujud Puji Nur Rahmat, 2019

Adapun praktik komunikasi visual keberagamaan dari dua tempat dan keadaan sekitar tersebut menggunakan tiga cara. Cara pertama, komunikasi visual foto dan video dilakukan sendiri-sendiri dengan menggunakan alat perekamnya sendiri-biasanya menggunakan telepon seluler smartphone. Cara kedua, komunikasi visual foto dan video dilakukan secara bersamasama, dengan menggunakan alat perekam salah seorang metalhead Indonesia yang terlibat dalam praktik kebergamaan tersebut. Cara ketiga, komunikasi visual foto dan video dilakukan secara bersama-sama, dengan menggunakan alat perekam salah seorang peserta keberagamaan atau umat Muslim Indonesia lainnya yang terlibat dalam praktik kebergamaan tersebut. Foto dan video komunikasi visual yang berhasil mengabadikan praktik keberagamaan para metalhead Indonesia pada tempat dan keadaan sekitar tertentu, diunggahnya dalam dua waktu.

Waktu pertama, setelah pendokumentasian selesai dan praktik kebergamaan masih berlangsung. Waktu kedua, ketika praktik keberagamaan selesai dan diunggahnya pun antara pada berjam-jam atau berhari-hari setelahnya. Adapun dalam mendapati komunikasi visual foto dan video yang diunggah metalhead Indonesia atau umat Muslim Indonesia lainnya, metalhead Indonesia yang juga terlibat dalam praktik keberagamaan menunggu kiriman dengan cara akun Facebooknya di-tag (dilabeli) oleh pengunggah komunikasi visual foto dan video tersebut. Mengenai komunikasi visual video, terdapat dua materi yang diunggahnya. Materi pertama, video yang tanpa pengubahan dari gambar yang aslinya, baik pengurangan maupun penambahan gambar dan segala komunikasi visual, baik tulisan, suara efek, maupun musik. Materi kedua, video yang diubah dari gambar aslinya. Pengubahannya terdapat dua jenis: pertama, pengurangan atau pemotongan gamabr asli; dan, kedua, penambahakan tulisan, suara efek, maupun musik pada gambar asli. Maksud dari pengubahan gambar, terutama pada penambahan tulisan, suara efek, dan musik, lebih kepada agar calon penonton memahami pesan yang disampaikan pengunggah video.

\section{Menyebarkan Informasi dan Pengetahuan yang Didapati di Facebook}

Pada metode ini dalam praktik visual kebergamaan metalhead Indonesia adalah menggunakan semua jenis komunikasi visual, yaitu tulisan, foto, meme, video, dan video siaran langsung. Adapun melalui metode ini metalhead Indonesia hanya sebagai penyebar berbagai jenis visual yang telah didapatinya. Merasa dianggap sesuai dengan pandangannya dalam keberagamaan, metalhead Indonesia tersebut meneruskan pengetahuan yang didapatinya. Namun, metalhead Indonesia yang menyebarkan pengetahun kebergamaan tersebut, tidak bisa 
menentukan jenis komunikasi visualnya. Jenis komunikasi visualnya ditentukan dari pengirim pengetahuan kebergamaan yang diterimanya.

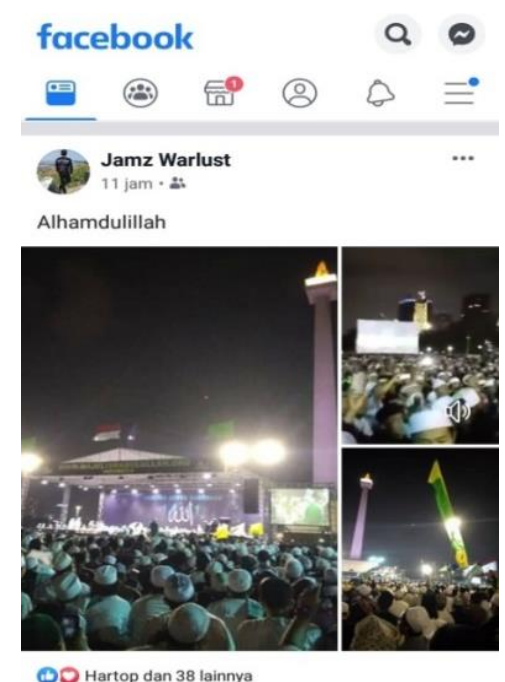

Gambar 7 Partisipasi Metalhead Indonesia menyiarkan secara langsung kegiatan keagamaan Islam di Monas melalui aplikasi video Facebook. Sumber: Sujud Puji Nur Rahmat, 2019

Adapun teknis penyebaran pengetahuan kebergamaan yang bebagai jenis visual tersebut terdapat tiga cara. Pertama, penyebaran pengetahuan keberagamaan dilakukan hanya di akun Facebooknya sendiri dan pengaturannya untuk umum sehingga siapaun bisa melihatnya, baik merupakan metalhead maupun non-metalhead. Kedua, penyebaran pengetahuan keberagamaan dilakukan di akun Facebooknya sendiri dan menautkan teman-teman Facebooknya, yang merupakan metalhead maupun non-metalhead, berjumlah sebanyak satu maupun lebih hingga mencapai puluhan. Ketiga, penyebaran pengetahuan keberagamaan dilakukan di satu akun grup Facebook atau lebih yang sebelumnya metalhed Indonesia tersebut sudah resmi bergabung dan grup Facebook yang terkait musik metal maupun non-musik-metal.

\section{Menyebarkan Segala Informasi Tentang Band Musik Metal Islami dari Dalam Negeri}

Pada metode ini dalam praktik visual kebergamaan metailhead Indonesia adalah menggunakan semua jenis komunikasi visual, yaitu tulisan, foto, meme, video, dan video siaran langsung. Adapun melalui metode ini metalhead Indonesia hanya sebagai penyebar berbagai jenis visual yang telah didapatinya dari band musik metal Islami tersebut. Seperti grup metal Purgatory dimana syair dan musik mereka mengusung nilai-nilai religius islami dalam karya musik dan pertunjukannya (Rahmat et al. "Musik Metal Dan Nilai Religius Islam: Tinjauan Estetika Musik Bermuatan Islami Dalam Penampilan Purgatory" 133). Materi kebergamaan band musik metal Islami dalam negeri yang disebarkannya antara lain terkait tema festival musik metal yang telah dan akan band tersebut tampil, karya lagu dan biografi band yang telah dan akan dirilis, segala atribut dari band musik metal Islami, dan segala kegiatan kebergamaan masing-masing maupun seluruh perssonil dari band musik metal Islami tersebut pada saat kegiatan yang terkait musik metal maupun non-musik metal. 


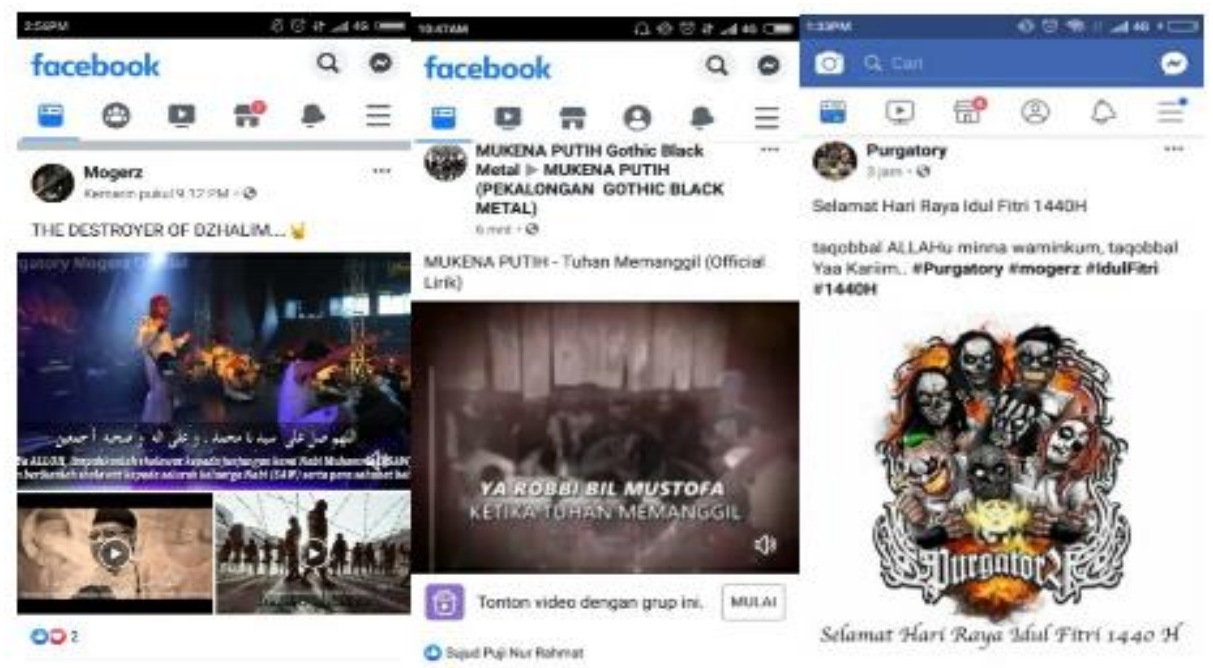

Gambar 8 Metalhead Indonesia menyebarkan informasi band metal Islami Indonesia menggunakan video dan ilustrasi di Facebook. Sumber: Sujud Puji Nur Rahmat, 2019.

Terkadang metahead Indonesia yang menyebarkan segala jenis visual band musik metal Islami dalam negeri juga menambahkan komunikasi visual tulisan sebagai tambahan dan pendukung. Memang, musik dan aspek-aspek atau tingkah laku lainnya dalam kehidupan manusia memiliki keterkaitan, sehingga pemahaman mengenai suatu kebudayaan dapat dicapai antara lain lewat studi terhadap musiknya (Irawati 3). Intinya, ada kesesuaian antara musik dengan aspek kehidupan lainnya, termasuk religi. Komunikasi visual tulisan sebagai tambahan dan pendukung adalah judul dan uraian. Judul dan uraian diperlukan agar maksud pesan dari pengunggah segala jenis komunikasi visual tersampaikan dan dipahami para pembaca. Tulisan judul dan uraian mengarahkan pembaca supaya fokus dan tidak melenceng dari maksud pesan yang disampaikan pengunggah.

\section{Teknis Berkomunikasi Visual dengan Sesama Teman Facebook}

Teknis berkomunikasi visual dengan sesama teman Facebook yang dilakukan metalhead Indonesia dalam mempraktikkan komunikasi visual bertema keberagamaan, terdapat tiga macam. Pertama, komunikasi visual dengan menggunakan empat jenis komunikasi visual dilakukan hanya di akun Facebooknya sendiri dan pengaturannya untuk umum sehingga siapaun bisa melihatnya. Kedua, komunikasi visual dengan menggunakan empat jenis komunikasi visual dilakukan di akun Facebooknya sendiri dan menautkan teman-teman Facebooknya, yang merupakan metalhead maupun non-metalhead, berjumlah sebanyak satu maupun lebih hingga mencapai puluhan. Ketiga, komunikasi visual dengan menggunakan empat jenis komunikasi visual dilakukan di satu akun grup Facebook atau lebih yang sebelumnya metalhed Indonesia tersebut sudah resmi bergabung dan grup Facebook yang terkait musik metal maupun nonmusik-metal.

Metalhead Indonesia yang berkomunikasi visual bertemankan keberagamaan, menggunakan berbagai jenis komunikasi visual, yaitu tulisan, foto, meme, video, dan video siaran langsung. Namun, dalam berkomunikasi visual tersebut lebih sering menggunakan komunikasi visual tulisan, daripada foto, meme, video, dan siaran langsung. Penggunaan jenis komunikasi visual dalam berkomunikasi visual bertemakan kebergamaan, disesuaikan dengan kondisi yang sedang dialaminya. Penggunaan komunikasi visual tulisan, ketika dalam kondisi bebas dari kegiatan kebergamaan maupun non-keberagamaan. Namun, komunikasi visual 
tulisan juga selalu dipakai sebagai komunikasi visual tambahan dan pendukung pada komunikasi visual lainnya, seperti foto, meme, video, dan video siaran langsung.

Pengertian sebagai pendukung dan tambahan dalam menggunakan komunikasi visual tulisan pada komunikasi visual lainnya, adalah judul dan uraian. Judul dan uraian diperlukan agar maksud pesan dari pengunggah tersampaikan dan dipahami para pembaca. Komunikasi visual tulisan judul dan uraian pada komunikasi visual lainnya, mengarahkan pembaca supaya fokus dan tidak melenceng dari maksud pesan yang disampaikan penggugah. Penggunaan komunikasi visual foto, terdapat dua kondisi yang dialaminya, yaitu sedang berkegiatan kebergamaan dan setelah kegiatan keberagamaan. Penggunaan komunikasi visual meme, ketika dalam kondisi bebas dari kegiatan kebergamaan maupun non-keberagamaan. Penggunaan komunikasi visual video, terdapat dua kondisi yang dialaminya, yaitu sedang berkegiatan kebergamaan dan setelah kegiatan keberagamaan. Penggunaan komunikasi visual video siaran langsung, ketika dalam kondisi bebas dari kegiatan kebergamaan.

\section{Simpulan}

Perjalanan berkomunikasi metalhead Indonesia terhadap sesama metalhead maupun masyarakat umum memiliki proses yang panjang. Sebagaimana yang dilakukan masyarakat umum serta sebagai tren masyarakat dunia dan Indonesia, metalhead Indonesia juga menggunakan media sosial Facebook, Whatsapp, dan Myspace sebagai media alternatif komunikasinya. Penggunaan media sosial yang dilakukan metalhead Indonesia selama 16 tahun dari 29 tahun keberadaannya, dan penggunaan Facebook merupakan terlama dibanding dengan Myspace dan Whatsapp, merupakan sebuah kontribusi tersendiri dalam budaya visual. Pengalaman metalhead Indonesia dalam berkomunikasi visual-selain komunikasi visual kehidupan sehari-hari gestur dan verbal.

Penyebab terjadi praktik penggunaan komunikasi visual alternatif secara terus menerus adalah adanya pengelolaan komunikasi visual yang didalamnya turut serta tekait dengan tema komunikasi tertentu yang diperbincangkan di media yang lengkap menampung berbagai jenis komunikasi visual karena empat hal yang saling terhubung. Pertama, media sosial Facebook bila dilihat dari satu sisi merupakan media komunikasi visual alternatif metalhead Indonesia. Tetapi dalam praktiknya, penggunaan Facebook yang sangat lama oleh metalhead Indonesia merupakan bukan media komunikasi visual alternatif. Melainkan media komunikasi visual yang terkait dengan komunikasi sehari-hari gestur maupun verbal. Berawal dari kehidupan seharihari gestur dan verbal dibawa ke Facebook lalu dari Facebook dibawa ke kehidupan sehari gestur dan verbal, dan praktik seperti itu yang dilakukan secara terus menerus tiada henti di titik tertentu. Maka itu, Facebook tidak bisa disebut sebagai sebuah media komunikasi visual alternatif.

Kedua, keberagamaan bila dilihat dari satu sisi merupakan sebagai tema alternatif. Tetapi dalam praktiknya, bila dilihat kehidupan metalhead Indonesia secara menyeluruh, kebergamaan tidak bisa dilepas dari kehidupannya; sehingga keberagamaan bukan sebagai sebuah tema alternatif. Walaupun metalhead Indonesia mengangkat tema komunikasi musik metal yang merupakan sebuah sub-kultur. Maka, bisa disebut bahwa metalhead Indonesia ialah kelompok yang mempraktikan perihal agama dan musik. Ketiga, Facebook menampilkan banyak jenis komunikasi visual. Jenis komunikasi visual tersebut, ialah tulisan, foto, meme, gambar atau poster, video, dan video siaran langsung. Metalhead Indonesia bisa menggunakan satu atau semua jenis komunikasi visual sebagai komunikasi visual pilihannya di Facebook. Keempat, praktik berkomunikasi visual keberagamaan di Facebook, metalhead Indonesia merupakan 
pelaku utama dalam empat tahap, yaitu memproduksi, menyalurkan, mengomunikasikan, dan memahami komunikasi visual tersebut. Merupakan empat tahap yang komunikasi visual yang membantuk sistem khusus.

Facebook bukan sebagai media komunikasi visual alternatif metalhead Indonesia. Namun, Facebook merupakan sebagai pelebaran atau penambahan tempat komunikasinya. Perbincangan tema agama dan musik metal merupakan sebuah oposisi biner bagi metalhead Indonesia, yaitu saling terkait satu sama lain sehingga menjadi satu kesatuan. Pembahasan musik metal tidak bisa lepas dari praktik keberagamaan. Muatan kebergamaan selalu diselipkan dalam lingkungan kebermusik-metalan. Berbagai jenis komunikasi visual yang disediakan Facebook-tulisan, foto, meme, gambar atau poster, video, dan video siaran langsungmenandakan keleluasaan metalhead Indonesia dalam berpraktik visual keberagamaan yang melibatkan banyak orang sehingga lebih masif dilakukannya komunikasi visual dibandingan di media sosial lainnya. Sistem khusus-memproduksi, menyalurkan, mengomunikasikan, dan memahami-praktik visual keberagamaan metalhead Indonesia di Facebook, yang merupakan sebagai dasar praktik visual kebergamaan metalhead Indonesia di media sosial.

\section{Daftar Pustaka}

Damono, Sapardi Djoko. Alih Wahana. Editum, 2014.

George, Kenneth M. "Designs on Indonesia's Muslim Communities." The Journal of Asian Studies, vol. 57, no. 3, 1998, pp. 693-713, doi:https://doi.org/10.2307/2658738.

Irawati, Eli. "Transmisi Kelentangan Dalam Masyarakat Dayak Benuaq." Resital: Jurnal Seni Pertunjukan (Journal of Performing Arts), vol. 17, no. 1, 2016, pp. 1-18, doi:https://doi.org/10.24821/resital.v17i1.1686.

Jones, Steve. "Music and the Internet." The Handbook of Internet Studies, edited by Robert Burnett et al., Wiley-Blackwell, 2010.

Jouili, Jeanette S. "Refining the Umma in the Shadow of the Republic: Performing Arts and New Islamic Audio-Visual Landscapes in France." Anthropological Quarterly, 2014, pp. 10791104, doi:https://doi.org/10.1353/anq.2014.0059.

Mazierska, Ewa. "Introduction: Setting Popular Music in Motion." Relocating Popular Music, edited by Ewa Mazierska and Georgina Gregory, Palgrave Macmillan, 2015.

Nasrullah, Rulli. Etnografi Virtual : Riset Komunikasi, Budaya Di Internet. Simbiosa Rekatama Media, 2017.

Nurgiyantoro, Burhan. Teori Pengkajian Fiksi. Gadjah Mada University Press, 2010.

Rahmat, Sujud Puji Nur. "Hasrat Bermain Dalam Festival Musik Metal Di Jakarta." Program Studi Pengkajian Seni Pertunjukan dan Seni Rupa Sekolah Pascasarjana vol. Doktor, Disertasi, Universitas Gadjah Mada, 2018. http://etd.repository.ugm.ac.id/home/detail pencarian/169343http://etd.repository. ugm.ac.id/home/detail pencarian/169343. 
Rahmat, Sujud Puji Nur et al. "Musik Metal Dan Nilai Religius Islam: Tinjauan Estetika Musik Bermuatan Islami Dalam Penampilan Purgatory." Resital: Jurnal Seni Pertunjukan (Journal of Performing Arts), vol. 18, no. 3, 2017, pp. 133-143, doi:https://doi.org/10.24821/resital.v18i3.3338.

Rahmat, Sujud Puji Nur et al. "Internet Dan Musik: Media Sosial Sebagai Wahana Publikasi the Upstairs Dan Death Flames." SELONDING, vol. 13, no. 13, 2018, pp. 1879-1891, doi:https://doi.org/10.24821/selonding.v13i13.2913.

Spradley, James P. Metode Etnografi. Tiara Wacana, 2007.

Stilt, Kristen. "Hisba, Arts and Craft in Islam." The Journal of the American Oriental Society, vol. no.

3,

2010,

$\mathrm{pp}$.

473-476, https://go.gale.com/ps/i.do?id=GALE\%7CA260285834\&sid=googleScholar\&v=2.1\&it=r \&linkaccess $=a b s \& i s s n=00030279 \& p=A O N E \& s w=w$.

Tinarbuko, Sumbo. Dekave Desain Kumunikasi Visual-Penanda Zaman Masyarakat. CAPS (Center for Academic Publishing Service), 2015.

Vardiansyah, Dani. Filsafat Ilmu Komunikasi Suatu Pengantar. PT. Indeks, 2008.

Wallach, Jeremy. "Underground Rock Music: And Democratization in Indonesia." World Literature Today, vol. 79, no. 3/4, 2000, pp. 16-20, doi:https://doi.org/10.2307/40158922. 